\title{
Dealing with the paradox of energy efficiency promotion by electric utilities
}

\author{
José Luís Sousa ${ }^{\text {a,c,* }}$, António Gomes Martins ${ }^{\text {b,c }}$, Humberto Jorge ${ }^{\text {b,c }}$ \\ ${ }^{a}$ Polytechnic Institute of Setúbal/Technology School of Setúbal, Setúbal, Portugal \\ ${ }^{\mathrm{b}}$ University of Coimbra, Coimbra, Portugal \\ ${ }^{\mathrm{c}}$ Institute for Systems Engineering and Computers at Coimbra (INESC Coimbra), Coimbra, Portugal
}

\section{A R T I C L E I N F O}

\section{Article history:}

Received 30 August 2012

Received in revised form 30 January 2013

Accepted 15 February 2013

Available online 17 March 2013

\section{Keywords:}

Demand-side management

End-use electricity efficiency

Utility incentives

Energy efficiency policies

System benefits charge

Energy efficiency resource standards

\begin{abstract}
A B S T R A C T
Utility-based Demand-Side Management (DSM) programmes started after the oil crises of the 70's and were adopted by utilities as a standard practice. However, deregulation of the electricity industry threatened DSM. More recent concerns regarding energy dependence and environmental impact of energy use caused renewed attention on the utilities role in energy efficiency fostering. EE is presently a cross-cutting issue, influencing energy policy definition and regulatory activity worldwide. Some instruments for influencing the behaviour of electric utilities in the market are used by regulators, corresponding to both impositions and stimuli, such as defining savings targets or decoupling profits from energy sales. The paper addresses categories of regulatory instruments and refers to examples of countries and regions using these identified categories of instruments. Although some cases show voluntary involvement of utilities in EE promotion on the grounds of customer retention strategies, there is a clear prevalence of regulatory constrained markets where utilities rationally engage in energy efficiency promotion.
\end{abstract}

(c) 2013 Elsevier Ltd. All rights reserved.

\section{Introduction}

The implementation of energy efficiency measures by utilities is, in abstract, a paradox. In fact, usually the incomes of a utility depend on the amount of energy sold, and so does the profit. Therefore, it is not an easy task to motivate utilities to engage in energy efficiency fostering strategies, mainly in a competitive environment. Nevertheless, nowadays it is very common to find energy efficiency programs implemented by utilities [1].

Energy efficiency and renewable energy sources are nowadays considered as the "twin pillars" of any sustainable energy policy [2]. Looking at developing countries, mainly those with very low electrification rates, the need to ensure an electricity supply adequate to a reasonable quality of life is of even greater importance. The infrastructures of the electricity system of those countries are usually old, fragmented and unreliable, with high technical and commercial losses, dependent on expensive and carbon intensive fuels. Power sectors in these countries are subject to increasingly frequent power shortage events. Although these events seldom have a single and the same cause, they are usually

\footnotetext{
* Corresponding author. Polytechnic Institute of Setúbal/Technology School of Setúbal, Setúbal, Portugal.

E-mail addresses: jose.luis.sousa@estsetubal.ips.pt (J.L. Sousa), agmartins@uc.pt (A.G. Martins), humberto.jorge@uc.pt (H. Jorge).
}

associated to underinvestment in infrastructures and increasing demand growth [3]. In these cases, the electricity system does not meet its purpose of ensuring the population needs. This inability to deliver the amount of energy required within acceptable quality parameters may be an opportunity for utilities to engage in DSM (Demand-Side Management), due to social and political pressure. Nevertheless, the fundamental economic interests of a utility still tend to undermine its involvement in DSM/energy efficiency programs over time. For electric utilities, implementing energy efficiency programmes represents, in the short-term, incurring upfront costs and, in the long-term, losing revenues from electricity sales due to lower consumption values. Therefore, usually only through regulation it is possible to engage utilities in energy efficiency programmes. Nevertheless, several strategies have been adopted by utilities to compensate for lost revenues. In order to overcome these barriers, for example, in the United States of America (US) Public Utilities Commissions allow a blend of programme cost recovery, remuneration of sales, and sharing of benefits of energy efficiency programmes [4,5].

In this paper we looked at the involvement of electric utilities in DSM activities in several countries. The countries analysed resulted mostly from the reunion of IEA/OECD countries and others whose information could be found in the Policy and Regulation Review Database of the Renewable Energy and Energy Efficiency Partnership (REEEP) website. Since the focus of this paper is the existing 
paradox of private interests engaged in activities that could reduce their own income, countries where none or practically non-existent, private entities in the electricity sector were not addressed. Being a work in progress, only a group of selected countries are addressed in this paper. The countries selected belong to one of three major groups: countries with long experience in DSM, emerging economies, and other developing countries. The allocation of public funds for DSM alternatives must be addressed in order to obtain the most societal benefits at the lowest possible cost [6].

This paper starts with a brief reference to DSM before the restructuring of the electricity sector, followed by the report of some of the impacts of the restructuring process. The strategies used to raise funds to be invested by utilities, as well as the imposition of energy efficiency targets are also presented. Some DSM experiences that received support from the World Bank and the evidence of the need of political engagement in DSM activities are then addressed. Also the Portuguese approach is reported.

\section{Utilities involvement in DSM activities before the electricity sector reform}

Utility-based Demand-Side Management (DSM) programmes started after the oil crises of the 70's. The unprecedented increase in oil prices showed the vulnerability of the economies of most countries. DSM programmes had their origin in policies implemented by the federal regulators and state public service commissions (PSC) in the US. Under the Public Utility Regulatory Policies Act of 1978, energy conservation issues were to be included in state utilities regulations. DSM programmes started as information campaigns and loan programmes. However, more aggressive programmes were needed to involve consumers. Higher financial incentives were needed to convince consumers to make more solid savings choices. Some programmes included cash rebates to stimulate consumers buying specific energy-efficient equipment. These financial incentives were a strong tool for utilities engaged in integrated resource planning (IRP). Under this planning approach, DSM alternatives are equally considered to other options based on increasing generating and network capacity [7]. The main motivation for these schemes was the cost-efficiency of the alternatives, and not their impacts on the environment and on the security of supply [8]. With DSM as an alternative in the planning process, an increase in the allocation of resources to new programmes was reported. Even so, the participation of consumers and the amount of savings obtained were not in line with the expectations. In order to obtain more savings and more participation, a more committed involvement of utilities was necessary. This involvement was accomplished through higher financial incentives and closer proximity of the utility with customers, not only during the purchase/installation of equipment, but in the long run, helping the customers getting more benefits from their participation in the programmes. This kind of involvement, not only had higher participation costs for the utility but also was time consuming, resulting in the possibility of serving only a relatively small number of consumers. A solution for this situation could be a "market transformation", meaning a change in the energy service and equipment so that the more efficient ones become the norm. Market Transformation (MT) alternatives included demonstration and training/information projects, and financial incentives, whose purpose was that after the MT initiative, the market penetration of the most energy efficient service/equipment would be near $100 \%$. This would mean that the market was transformed. The customer would be presented with the best solutions, without the need for any additional resources. However MT alternatives require a contribution from diverse parties and demand some considerable organizational efforts.

\section{Restructuring of electricity sectors}

Before the 1990s, when the movement towards restructuring of the electricity sector began, DSM programmes included information, financial assistance and direct installation of energy-efficient equipment. After the 1990s, these programmes were already standard practice for many utilities, changing their business to include provision of energy services, besides selling energy. Although standard practice, the deregulation of the electricity industry, which was occurring at the same time, threatened DSM programmes, due to lack of funding. The competition that resulted from the restructuring of the electricity sector reduced significantly the incentive for utilities to invest in energy efficiency measures, despite the opportunities that can emerge in the new market structures [9]. Although it was argued that the liberalization of the electricity sector would have a catalytic role in the creation of an energy efficiency market, the truth is that this did not happen $[10,11]$. Energy efficiency services were expected to be an asset to keep and gain more customers. Instead, the effort was put in the marketing and in the sales departments. Thus, not only the electricity sector did not become more energy efficient, as neither the security of supply nor the environmental impact was addressed [8]. The overlapping between commercial and societal interests is one of the major disadvantages of the utilities involvement in promoting energy efficiency on the demand side. Another is the competitive disincentive to incur in programme costs, increase prices or reduce sales due to programme success. However, the advantages are considered to supersede the disadvantages. They are ready access to capital, proximity to the customer (including billing system and access to consumption data), familiar brand name, and responsibility to anticipate and accommodate energy and peak demand growth [12]. Prior to system reform, electric utilities in developed countries had the means, the money, and the interest in investing in the promotion of energy efficiency measures. In developing countries, on the other hand, privatisation was a means to deal with the lack of funds to invest in the modernization/maintenance of the electricity systems. The electricity systems were characterised by relatively low electrification rates, high distribution and commercial losses, vulnerable to climate changes (mainly drought), and consequent dependence on expensive energy resources. In some countries, even without the minimum admissible quality of service, the electricity tariffs were even higher than in developed countries or highly subsidized $[13,14]$. This was the case of India where, for example, tariffs to agricultural consumers were subsidized to $80 \%-90 \%$ in some states [15]. Either way, DSM could present itself as a way to reduce power shortages and mitigate climate influence in energy supply, both reducing energy needs and supply costs.

Although Chile was the first country in the world to reform the electricity sector, in 1982, California is perhaps the most commonly reported, at least regarding DSM before and after the restructuring of the electricity sector. California was the first US state to restructure the electricity sector, in 1994, with the aim of giving to the customers the power to choose their supplier. By 2000, the electricity sector of 21 more US states and the District of Columbia were under a new regulatory environment. In this regulatory environment, electric utilities had much less funds to spend in DSM programmes. Since 1995 there was a reduction of the contribution of DSM to mitigate demand growth in relative terms and to reduce peak demand in absolute terms [16]. Due to the uncertainties about newly restricted markets and the expected loss of cost recovery mechanisms, the funding for ratepayer-funded energy efficiency programmes reduced from almost $\$ 1.8$ billion in 1993 to $\$ 900$ million in 1998 (nominal dollars). In fact, from 1993 to 1999, the decline in utility spending in DSM was 55\% [17]. Noting that the 
reduction of spending in DSM was related to deregulation, states started setting mechanisms to restrain it. A public benefit fund (PBF) was then established by the regulators to fund DSM programmes, more precisely to fund energy efficiency programmes, renewable energy, low-income assistance and other public-interest energy R\&D. This way all ratepayers contribute to activities that are considered of public interest [18]. These PBF were funded by a "wires charge", addressed as "public benefits charge", "public goods charge" or even "systems benefit charges".

\section{Funding energy efficiency utility programmes}

Systems benefits charges (SBC) are added to all electricity bills. SBC can be collected as a percentage of gross annual utilities revenues, fixed values per $\mathrm{kWh}$ or fixed amounts. The reasons behind programmes financed by these charges were not related to providing electricity system resources (that was a "market" responsibility) but to support the benefits of energy efficiency to the society. The energy efficiency programmes financed by these charges are usually managed by utilities and include financial incentives such as loans, grants, and rebates.

In Denmark, since 2006, distribution electric utilities (as well as natural gas and district heating) are obliged to promote energy efficiency, although electric utilities have been working actively in energy efficiency fostering since 1990. The funds to invest in energy efficiency come from a component of the electricity tariffs [19]. Simultaneously, distribution companies also had to provide, free of charge, information on energy savings, individual energy advice to households, energy advice to companies, institutions, and public services, and research and development of new technologies. Among energy efficiency activities conducted by distribution companies are the access they provide to energy meters, for example, for individual appliances in order for the customer to be informed of the amount of energy those appliances consume. They also give the consumer access to demonstration facilities where he can experience new and more efficient technologies. Competitions to find the most energy-efficient company or municipality are also organized by distribution companies as a strategy to improve energy efficiency. Every three years, distribution companies have to plan activities according with the guidelines issued by the Danish Energy Authority (DEA) and every year report the success of their measures. Unlike before, nowadays, the money collected in each consumer group does not have to be invested in measures in that same consumer group, nor within the company franchised area [20].

The Portuguese energy regulator (ERSE) developed a tender mechanism to promote energy efficiency in electricity consumption (PPEC), with a track record of four calls for proposals. This tender mechanism, an actual market transformation instrument, is subject to an annual budget, coming from electricity tariffs paid by all electricity consumers. Selected measures, to be implemented by the promoters, are partly financed by this budget and must contribute to increase energy efficiency in electricity end-use. Among promoters are electricity suppliers, network operators, and consumer organizations, targeting different consumer segments (industrial, agricultural, residential, commerce and services). For the last three calls, the number of utilities proposing measures increased, although the number of measures proposed has decreased [21-23]. The candidate measures must aim a lasting reduction of electricity consumption or load management in a way that can be easily verified and accounted for. These measures are classified as tangible ("hard"). A different kind of measures intangible ("soft") measures - that promote information and dissemination, can also be proposed to this tender. Even not having measurable impacts, they can contribute to more rational behaviours and help decision making regarding the adoption of more energy efficient solutions. From the 2008 to the 2011 calls for proposals, there seems to be a trend for utilities to invest more in tangible measures over intangible ones. Although reducing the total number of proposed measures, the number of tangible measures increased. The proposed measures are usually financed by the PPEC funds, by the promoter and by the consumer. There has been an increasing financial contribution of utilities to the measures they proposed along with the reduction of the contribution of consumers. Even without a decoupling mechanism such as some kind of compensation for the reduction of sales, electric utilities investment in end-use energy efficiency activities seems to be increasing. Fostering energy efficiency seems to be gaining the status of a brand.

In California, the customers started paying similar charges, in 1996, for a four-year period. The period was then extended to 2012. By 2000, the utilities spending on DSM was increasing due to state encouragement of PBF. In fact, after the decrease occurred between 1993 and 1998/99, the total budget spent in electric energy efficiency programmes rose and was around $\$ 4.5$ billion by 2010 [24]. In Connecticut, the electricity distribution companies and municipal electricity companies provide portfolios of energy efficiency programmes to their customers. The energy efficiency programmes are administered by the utilities and implemented by them and by the contractors they hire. The Connecticut Energy Efficiency Fund (CEEF), funded by a charge in customer's energy bill, was created in 1999 as a response to the increase of energy demand and costs [25]. The funds for the energy efficiency plans in Massachusetts come from the SBC, from revenues of the ISO New England Forward Capacity Market, from the Regional Greenhouse Gas Initiative (RGGI) - a multi-state market-based emissions trading scheme, and from an adjusting distribution charge approved by the Department of Public Utilities (DPU), to the extent necessary to be able to procure all cost-effective energy efficiency and demand resources [26].

An SBC is suggested to overcome the financial "bottleneck" that China is experiencing [11]. According to Yu [11] these SBC will not only provide stable and sufficient funding for DSM programmes, but also involve all society in participating in energy efficiency improvements. It is expected that SBC will help to overcome the difficulties experienced and can help bridge the gap between the pilot studies that have been implemented since the early 1990s and the full adoption of a DSM framework. In fact, in January 2011, a DSM regulatory framework came into force, where power grid companies are obliged to obtain energy savings that amount, at least, $0.3 \%$ in sales volume, and $0.3 \%$ in maximum load, compared with their previous year [27].

In Brazil, the regulatory agency, ANEEL, set a $1 \%$ of annual net revenues of private utilities that should be invested in energy efficiency and R\&D projects. Since 2000 , the measures had to focus on end-use energy efficiency, and the $1 \%$ obligation was extended to transmission and generation companies, both private and stateowned. Part of those amounts was to be invested by utilities and another part was collected by a PBF, the CTEnerg. The CTEnerg was also in charge of funding energy efficiency programmes. After 2003 the obligation rose to $1.1 \%$ [28]. On the other hand, governmentowned utilities execute and co-finance the PROCEL, a national programme for electricity conservation, in operation since 1985. PROCEL receives funds from the Global Reversion Fund (a federal fund that receives resources from concessionary companies) and also from international entities such as the GEF [29]. Such as in Portugal, in Brazil some utilities have used energy efficiency programmes as a strategy to retain non-franchise customers, mainly large consumers [27]. Also in the US, during the restructuring of the electricity sector, while some utilities reduced investment in DSM programmes, others were still maintaining some investment, seeing DSM as a value-added alternative to retain customers [30]. 
Besides the SBC, the funds for DSM programmes can come from revenue from differentiated electricity prices, and other government budget allocations. Also some expenses may be incorporated into power supply cost [27]. In the Indian states of Delhi and Maharashtra, electricity regulators have allocated electricity sector revenues for pilot DSM programmes. Consumer tariffs usually increase when energy efficiency programmes are financed using utilities revenues, leading to a probable reduction of sales. However, no large-scale energy efficiency programmes have been implemented in India using resources from utilities [31]. Besides charges paid by all customers, new methods to set tariffs, and performance standards, were identified in South Africa, as new important regulatory interventions to allow that the benefits of energy efficiency could be enjoyed by the less fortunate [32].

The availability of funds to energy efficiency programmes managed by utilities is a key factor to involve utilities in developing DSM programmes. The loss of revenues that utilities may experience due to successful DSM programmes may be discouraging and are, therefore, addressed by some countries, mainly the US, by decoupling revenues from $\mathrm{kWh}$ sales. Decoupling is a process used to compensate utilities by the reduction of sales due to energy efficiency programmes. The rates are periodically adjusted to reflect the difference between actual energy sales and the sales forecast used in the rate setting process.

Imposing the investment of certain amounts in energy efficiency measures is no guarantee of investment in the most suitable options, regarding the societal objectives pursued. Some countries impose, by regulation, energy reduction targets to guarantee utilities involvement in energy efficiency activities, thereby contributing to the reduction of energy resources depletion and environmental impact of energy use with the best performing measures.

\section{Energy efficiency obligations}

After a growing number of system reliability problems that culminated with the California energy crises in the winter of 20002001, utilities attention was more directed to programmes with short-term results, although continuing stimulating customer purchases of energy efficient equipment, mainly under MT programmes. The focus of energy efficiency programmes was again set on their ability to be considered as a system resource. In order to overcome energy and demand restrictions, new and innovative programmes as well as programmes that had already proven to be effective were launched. Additionally, higher savings per customer were targeted by the utilities [33]. Utilities with long experience in implementing EE programmes are investing in gathering consumer information, as much as possible, in order to be able to design the most appropriate programmes. These usually require the combination of different end-uses, such as lighting (several technologies), HVAC, insulation, among others, independently of the energy carrier, and even in cooperation between electricity and gas utilities. These approaches usually require collaborative efforts with other entities. Utilities are improving the relation utility-customer, under the assumption that a better relation ease customers participation both in programmes and in E\&V procedures, acting also as a customer retention strategy. With a good relation with customers it is easier to gather information that will allow the design of new programmes intended to maximize the savings per customer.

Energy Efficiency Resource Standards (EERS) arise in this context as a market-oriented mechanism that requires utilities to achieve certain targets of energy savings through energy efficiency activities. In European countries EERS are commonly addressed as Energy Efficiency Obligations (EEO). These EERS/EEO schemes are very similar to the Renewable Portfolio Standards (RPS) policy that requires minimum amounts of energy to be obtained by renewable sources. The energy savings targets of the EERS/EEO could be set as a minimum amount or a percentage of the total system supply. The US state of Texas was the first to establish EERS, in 1999, for electric utilities. The Texas electric utilities were required, by the electricity restructuring law, to obtain a $10 \%$ offset of their demand growth by end-use energy efficiency activities. This target was easily achieved and even exceeded. By 2011 there were more 25 US states with EERS activities for electricity. The savings obligations can be set on an annual basis or a cumulative amount for the whole period of the mechanism duration. Also the targets can vary from one utility to the other - Tailored utility targets. For instance, the states of Massachusetts, Vermont, Illinois, Minnesota, Iowa, Rhode Island, Ohio, Indiana, Maine, Colorado, Wisconsin, Connecticut (ended in 2011), California, Michigan, Washington, Arkansas, and Oregon set targets on an annual basis. The states of Vermont, New York, Maryland, Pennsylvania, New Mexico, Nevada, Hawaii, North Carolina, Texas, Florida, and Delaware set cumulative targets for a period of time. The states of Vermont, Iowa, Rhode Island, Maine, Colorado, and Oregon have tailored utility targets. The states of Nevada, Hawaii and North Carolina have EERS saving targets combined with RPS. Together with the obligation, the majority of the states allow utilities to receive a percentage of the net benefits and/or of the programme costs, when they achieve near $100 \%$ of the savings goal and an even higher percentage if they exceed the targets [25]. In Table 1 a summary of the main characteristics of the involvement of utilities in EE programmes in the US is presented.

The EERS/EEO can provide some flexibility for the targets to be achieved through market-oriented mechanisms, such as energy efficiency trading schemes: those utilities that save more than their target can trade with others that did not fulfil their obligations. In some countries the savings obtained by utilities can be certified, and a "white certificate" is issued. This is the case of the Flemish region of Belgium, Denmark, France, Italy, and UK, alongside with Canada and New South Wales, in Australia. The 2005 Action Plan for Renewed Energy Conservative Efforts, of Denmark, calls for energy savings through building codes and obligations, both in the public sector and through distribution companies. The Action Plan imposed that the energy efficiency measures that the distribution companies had to implement in order to increase energy savings should be done without any tariff adjustment to cover additional costs. The companies have to be more cost-effective in achieving savings otherwise they will lose money. The companies are free to choose the methods and the consumer targets, and also allowed to trade obligations. Under this new plan distribution companies do not need Danish Energy Authority (DEA) approval of the actions they intend to implement. The companies are no longer restricted to their jurisdiction area, neither for the implementation of energy efficiency measures nor are they limited to invest the amounts received from one group in that same group of customers. When a company implements measures to customers of a different company's jurisdiction, the savings account to this latter company but a payment is due to the company that implemented the measures. This allows the specialization of companies in measures for certain groups of consumers, such as residential, industrial, etc. Also, they are now able to trade obligations. Those companies that could save above their obligations are allowed to sell to those that did not reach theirs [20].

Energy efficiency certificates (white certificates) were introduced in New South Wales (NSW) in 2003, as part of the Greenhouse Gas Reduction Scheme (GGAS). GGAS was intended to reduce greenhouse gas emissions related to production and use of electricity and to promote activities that should offset Greenhouse gas (GHG) emissions. In 2005 the GGAS was extended to the Australian Capital Territory (ACT). Under the GGAS, certain obliged parties (addressed as benchmark participants) have individual benchmark 
Table 1

Main characteristics of utilities involvement in energy efficiency programmes, in the US.

\begin{tabular}{|c|c|c|c|c|}
\hline State & $\begin{array}{l}\text { Mandatory } \\
\text { involvement }\end{array}$ & $\begin{array}{l}\text { Mandatory } \\
\text { targets }\end{array}$ & $\begin{array}{l}\text { Voluntary } \\
\text { involvement }\end{array}$ & $\begin{array}{l}\text { Performance } \\
\text { incentive }\end{array}$ \\
\hline Alabama & No & No & Yes & - \\
\hline Alaska & No & No & Yes & - \\
\hline Arizona & Yes & Yes & $\mathrm{n} / \mathrm{a}$ & Yes \\
\hline Arkansas & Yes & Yes & $\mathrm{n} / \mathrm{a}$ & Yes \\
\hline California & Yes & Yes & $\mathrm{n} / \mathrm{a}$ & Yes \\
\hline Colorado & Yes & Yes & $\mathrm{n} / \mathrm{a}$ & Yes \\
\hline Connecticut & Yes & Yes & $\mathrm{n} / \mathrm{a}$ & Yes \\
\hline Delaware & No & Yes & Yes & Yes \\
\hline District of Columbia & No & No & $\mathrm{n} / \mathrm{a}$ & Yes \\
\hline Florida & Yes & Yes & $\mathrm{n} / \mathrm{a}$ & Yes \\
\hline Georgia & No & Yes & $\mathrm{n} / \mathrm{a}$ & Yes \\
\hline Hawaii & Yes & Yes & $\mathrm{n} / \mathrm{a}$ & Yes \\
\hline Idaho & No & No & $\mathrm{n} / \mathrm{a}$ & Yes (pending) \\
\hline Illinois & Yes & Yes & $\mathrm{n} / \mathrm{a}$ & No \\
\hline Indiana & Yes & Yes & $\mathrm{n} / \mathrm{a}$ & Yes \\
\hline Iowa & Yes & Yes & $\mathrm{n} / \mathrm{a}$ & No \\
\hline Kansas & No & No & Yes & Yes \\
\hline Kentucky & Yes & Yes & $\mathrm{n} / \mathrm{a}$ & Yes \\
\hline Louisiana & No & No & Yes & Yes \\
\hline Maine & Yes & Yes & $\mathrm{n} / \mathrm{a}$ & Yes \\
\hline Maryland & Yes & Yes & $\mathrm{n} / \mathrm{a}$ & Yes \\
\hline Massachusetts & Yes & Yes & $\mathrm{n} / \mathrm{a}$ & Yes \\
\hline Michigan & Yes & Yes & $\mathrm{n} / \mathrm{a}$ & Yes \\
\hline Minnesota & Yes & Yes & $\mathrm{n} / \mathrm{a}$ & Yes \\
\hline Mississippi & No & No & Yes & No \\
\hline Missouri & No & No & Yes & Yes \\
\hline Montana & Yes & No & $\mathrm{n} / \mathrm{a}$ & Yes \\
\hline Nebraska & Yes & No & $\mathrm{n} / \mathrm{a}$ & - \\
\hline Nevada & Yes & Yes & $\mathrm{n} / \mathrm{a}$ & Yes \\
\hline New Hampshire & Yes & No & $\mathrm{n} / \mathrm{a}$ & Yes \\
\hline New Jersey & Yes & No & $\mathrm{n} / \mathrm{a}$ & - \\
\hline New Mexico & Yes & Yes & $\mathrm{n} / \mathrm{a}$ & Yes \\
\hline New York & Yes & Yes & $\mathrm{n} / \mathrm{a}$ & Yes \\
\hline North Carolina & Yes & Yes & $\mathrm{n} / \mathrm{a}$ & Yes \\
\hline North Dakota & No & No & Yes & No \\
\hline Ohio & Yes & Yes & $\mathrm{n} / \mathrm{a}$ & Yes \\
\hline Oklahoma & Yes & Yes & $\mathrm{n} / \mathrm{a}$ & Yes \\
\hline Oregon & Yes & Yes & $\mathrm{n} / \mathrm{a}$ & No \\
\hline Pennsylvania & Yes & Yes & $\mathrm{n} / \mathrm{a}$ & No \\
\hline Rhode Island & Yes & Yes & $\mathrm{n} / \mathrm{a}$ & Yes \\
\hline South Carolina & No & No & Yes & - \\
\hline South Dakota & No & No & Yes & Yes \\
\hline Tennessee & No & No & Yes & No \\
\hline Texas & Yes & Yes & $\mathrm{n} / \mathrm{a}$ & Yes \\
\hline Utah & Yes & No & $\mathrm{n} / \mathrm{a}$ & No \\
\hline Vermont & Yes & Yes & $\mathrm{n} / \mathrm{a}$ & Yes \\
\hline Virginia & Yes & No & $\mathrm{n} / \mathrm{a}$ & No \\
\hline Washington & Yes & Yes & $\mathrm{n} / \mathrm{a}$ & No \\
\hline West Virginia & Yes & No & $\mathrm{n} / \mathrm{a}$ & No \\
\hline Wisconsin & Yes & Yes & $\mathrm{n} / \mathrm{a}$ & Yes \\
\hline Wyoming & No & No & Yes & No \\
\hline
\end{tabular}

n/a - not applicable; “-“ - no information was gathered. Sources: [45-50].

targets for GHG emissions. These benchmark participants are all electricity retailers that supply customers in NSW and ACT, generators that supply electricity directly to end-use customers in NSW and ACT, and all NSW and ACT customers that buy electricity directly from the wholesale National Electricity Market. The benchmark targets are set per capita, regarding the population of NSW and ACT [34].

In Italy, the utilities involvement in energy efficiency initiatives is mostly achieved through the Energy Efficiency Certificates scheme. This scheme started in 2001 and intends to certify primary energy savings achieved through measures directed to energy consumers. The certificates are valid for 5 years and are issued by the electricity market operator (GME) to utilities and Energy Service Companies (ESCOs). Electricity or gas distributors serving more than 50000 customers are obliged to improve energy efficiency under this scheme. The certificates can also be issued regarding savings in natural gas. The individual savings targets are set annually, for each distributor, and based upon the ratio between the amount of energy distributed to their customers and the total amount of energy distributed in the country. The certificates can be traded through bilateral contracts or in the market.

DSM programmes in the UK are usually regulatory measures, either as white certificates or as energy saving obligations set by the government [35]. Under the Energy Efficiency Commitment (EEC), since 2002, electricity and gas utilities are required to achieve energy efficiency targets in the households sector. The targets for each supplier are set by the regulator, Ofgem. The utilities are free to choose the means to fulfil their obligations. They can, for instance, promote high-efficient lamps, boilers and appliances, and install insulation. However, at least half of their savings obligations have to be obtained in the "priority sector" (households that receive income-related benefits and/or tax credits), and the savings obligations can be traded among suppliers. There is no loss compensation mechanism. It was considered that since utilities are in a competitive environment, they are competing for their market share, and can pass through the costs of these measures as much as possible. So far there were three phases of EEC. The first phase (EEC1) ran from 2002 to 2005, the second phase (EEC2) between 2005 and 2008, and the third (EEC3) ran from 2008 to 2011. The savings amounts above the obligation target can be carried over to the next period. In case of non-compliance, obliged suppliers suffer a penalty equal to $10 \%$ of their revenue [36]. IEA [36] considers that the success of the EEC programme is due to four main factors. Firstly, since obligations are put on a limited number of energy suppliers, the programme management is relatively simple. Secondly, the savings are simple to calculate. A list of measures that the suppliers can implement with the savings they can lead to, are published by Ofgem. This procedure relieves the amount of work involved. Thirdly, there have been a lot of "easy to get" savings. Fourthly, some synergies with the Energy Savings Trust (EST) have been exploited. The EST is an independent body whose purpose is to promote energy efficiency and emissions reduction in households. Its main activities are enhancing awareness, and providing advice and technical support to energy efficiency alternatives. The support to the development of new and more energy efficient services and appliances is also accomplished by stimulating partnerships, innovation, providing training, and accreditation. The EEC-3 was re-named Carbon Emission Reduction Target (CERT). The share of savings that had to be obtained in the priority sector reduced from $50 \%$ to $40 \%$. In the UK the obliged parties have to

Table 2

Main characteristics of utilities involvement in energy efficiency programmes, in different countries.

\begin{tabular}{lllll}
\hline Country (Region) & $\begin{array}{l}\text { Mandatory } \\
\text { involvement }\end{array}$ & $\begin{array}{l}\text { Mandatory } \\
\text { targets }\end{array}$ & $\begin{array}{l}\text { Voluntary } \\
\text { involvement }\end{array}$ & $\begin{array}{l}\text { Performance } \\
\text { incentives }\end{array}$ \\
\hline Australia (NSW) & Yes & Yes & n/a & No \\
Belgium (Flanders) & Yes & Yes & n/a & No \\
Brazil & Yes & Yes & n/a & - \\
Canada (Ontario) & Yes & Yes & n/a & Yes \\
Canada & Yes & Yes & - & - \\
$\quad$ British Columbia) & & & & \\
China & Yes & Yes & n/a & Yes \\
Denmark & Yes & Yes & n/a & Yes \\
France & Yes & Yes & n/a & No \\
India & No & No & - & - \\
Italy & Yes & Yes & n/a & Yes \\
Portugal & No & No & Yes & No \\
South Africa & No & No & - & - \\
Sri Lanka & No & No & - & - \\
Thailand & No & No & Yes & - \\
UK & Yes & Yes & n/a & Yes \\
Vietnam & No & No & Yes & - \\
\hline
\end{tabular}




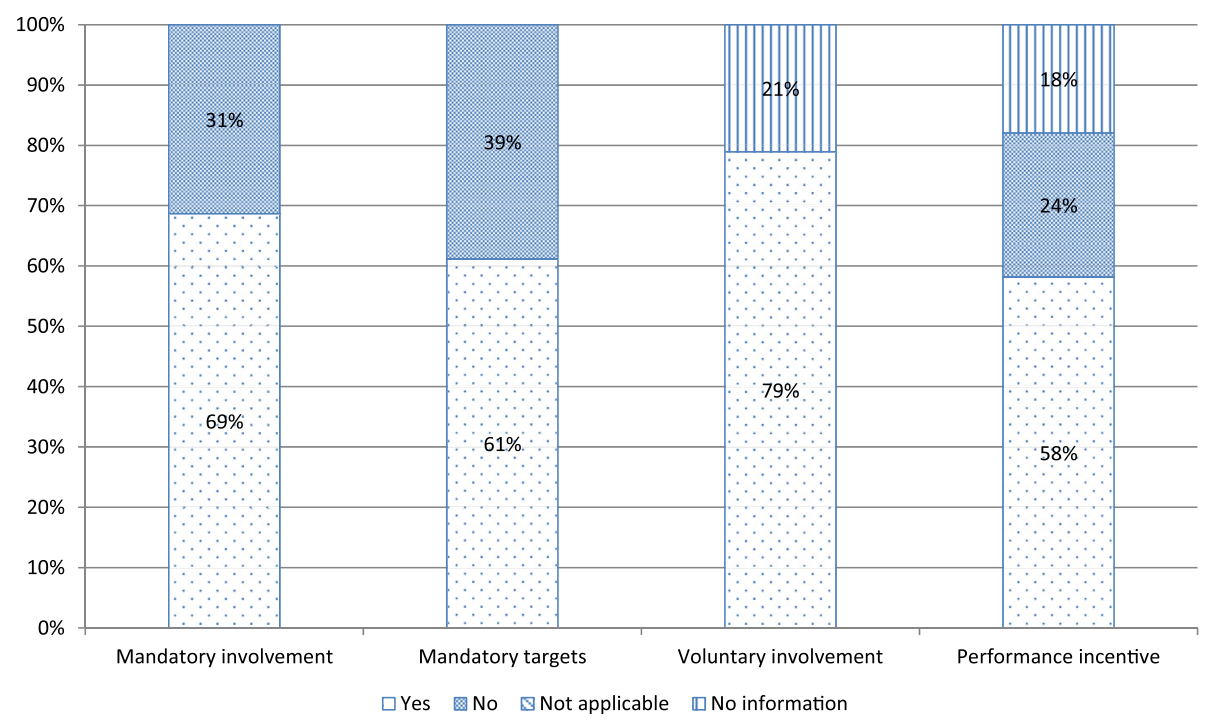

Fig. 1. Relative importance of the involvement of utilities in EE promotion in studied countries.

present their energy savings plans to the regulatory authority for pre-approval. The obliged utilities are those with more than 50,000 residential customers [12,36-38].

In France, since 2006, energy suppliers are obliged to achieve energy savings targets for a time period. They will receive a "white certificate" for the energy savings they managed to obtain. An energy supplier that, by the end of the period, was not able to fulfil its obligations, can buy certificates from other utilities that outperformed, otherwise it has to pay a penalty for each kWh not obtained. At the beginning, energy efficiency measures proposed by utilities under this scheme targeted the residential sector. Nowadays, other companies besides energy suppliers may participate in this scheme. The results obtained for the first phase, 2006-2009, surpassed the target. A reformulation of this scheme is under way regarding the entry of new market players and the need to ensure that the savings are obtained in a cost-effective way [39].

In the Flanders region of Belgium, the operators of the electricity distribution network are obliged to accomplish a $2 \%$ of annual primary energy savings in the residential sector, and $1.5 \%$ for nonresidential customers. The white certificates thereof can also be traded among obliged parties [40].

EERS/EERO is a strategy to force utilities involvement in energy efficiency fostering activities. Setting energy efficiency targets, more than just imposing amounts of money to be invested in energy efficiency measures, lead to the choice of the most costeffective measures. To exceed the savings targets is an opportunity for utilities to earn more money, either through a percentage of net benefits and/or programme costs, or through the possibility of selling the excess on the market. When no loss compensation mechanism exists, these strategies may foster utilities efforts.

It has been proven by experience in some countries (for example, already referenced $[20,24,36]$ ) that energy-efficiency and DSM programmes are much more cost effective than investing in all types of electricity supply, including renewable ones. Prompting feed-in tariffs but not energy efficiency and DSM programmes will end up costing more to utilities and consumers [41].

\section{Political engagement in DSM activities}

Several international organizations, such as the World Bank, The United Nations Development Programme (UNDP), the United States Agency for International Development (USAID), have been financing DSM activities, through loans, some of them with grants from Global Environment Facility (GEF). These projects arise mostly as strategies to avoid load supply interruption, due to poor electricity services, high commercial and technical losses, growing demand rates, high costs of supply, and/or low prices to customers. In these cases utilities can find an incentive to implement DSM programmes by influencing customers to reduce demand. Among other countries that received assistance from the World Bank, we may highlight Argentina, Bangladesh, Botswana, Croatia, Ethiopia, Jamaica, Mexico, Rwanda, Sri Lanka, South Africa, Thailand, Uganda, Uruguay, and Vietnam. Although most of these projects were successful, the lack of political engagement did not allow the experience to work as a starting point to the sustainability and durability of DSM programmes. The Thai project was considered quite successful as a market transformation one. During the project period, the government allowed a tariff charge to finance the project. After that, the Electricity Generating Authority of Thailand (EGAT) started funding DSM initiatives through its regular tariff revenue, since they found DSM programmes to be worthwhile in their ability to improve EGATs public image. But the funds eventually decreased for the most part. Then, DSM was supported by the government but not required by the regulations. A similar situation can be found in Vietnam. In accordance with Vietnamese regulations, the government has to consider DSM but there seems to be no imposition for the utilities to invest in DSM $[3,42]$. Some studies were conducted in Oman that concluded that despite the high potential for DSM and energy conservation measures there has been no corresponding effort from the government to promote them [43,44]. A government clear message is needed in order to involve private actors in effective DSM programmes. Hence, political will is fundamental in order to reduce uncertainty, clearing the government line of action [9].

In Table 2 a summary of the main characteristics of the involvement of utilities in EE programmes, in some countries, is presented (the US particular case was summarized in Table 1, Section 5).

\section{Conclusions}

Different approaches have been adopted to overcome the paradox of utilities involvement in energy efficiency fostering: by regulatory impositions, by sharing costs and benefits, and even as a marketing strategy. Through regulation, funds are channelled to DSM activities and energy savings targets are set. Some flexibility 
could be found regarding the way utilities choose to foster end-use energy efficiency. The loss of revenues due to successful DSM programmes is addressed by direct compensation, such as in the decoupling strategies, or rewarding utilities for the success they obtain with the measures they promote.

There are some cases where utilities invest in DSM for the sake of their market share, as a customer retention strategy. The image of a utility that promotes energy efficiency seems to be also valued as an intangible asset, once it is associated to societal objectives, valued by the public opinion. Labels such as "friend of the environment" or "organization concerned with climate change" seem to be considered as a potentially distinctive mark, a way of market positioning against competitors. However, the majority of the situations world-wide reveal that regulatory instruments are extensively used for ensuring utilities involvement in energy efficiency promotion: mandatory activities towards end-use energy efficiency promotion, minimum savings targets, decoupling mechanisms, benefit sharing, are some of the main regulatory instruments used for the purpose. Regulators tend to use ways of influencing corporate behaviours, through stimuli and obligations that lead utilities to adapt to this type of constrained market, towards energy sustainability goals, most of the times set by government energy policy guidelines.

For the group of countries/jurisdictions studies presented in this work, it was found that majority of the involvement is mandatory (Fig. 1). In Fig. 1, voluntary involvement figures are related to the countries/jurisdictions whose involvement is not mandatory. Also more than half the countries/jurisdictions have incentives to involve/compensate utilities for the participation in $\mathrm{EE}$ programmes.

As a final remark, the importance should be stressed of legal/ regulatory frameworks that specifically create the appropriate conditions for utilities to foster efficiency of energy use, driven by societal objectives, ensuring their economic and financial balance as well as maintaining, or even improving, their competitiveness.

\section{Acknowledgements}

This work has been partially supported by FCT under project grant PEst-C/EEI/UI0308/2011.

\section{References}

[1] Sciortino M, Neubauer M, Vaidyanathan S, Chittum A, Hayes S, Nowak S, et al. The 2011 state energy efficiency scorecard. Washington: ACEEE; 2011.

[2] Prindle B, Eldridge M, Eckhardt M, Frederick A. Twin pillars of sustainable energy: synergies between energy efficiency and renewable energy technology and policy. Washington D.C.: American Council for an Energy Efficient Economy. Retrieved 09 07, 2011, from: http://aceee.org/research-report/e074; 2007.

[3] Heffner G, Maurer L, Sarkar S, Wang X. Minding the gap: world Bank's assistance to power shortage mitigation in the developing world. Energy 2010;35:1584-91.

[4] Taylor RP, Govindarajalu C, Levin J, Meyer SA, Ward WA. Financing energy efficiency lessons from Brazil, China, India, and beyond. Washington D.C.: The World Bank; 2008.

[5] Baxter L. Net lost revenue adjustment (NLRA) mechanisms for utility DSM programs. Energy 1995;20:1215-23.

[6] Baskette C, Horii B, Kollman E, Price S. Avoided cost estimation and postreform funding allocation for California's energy efficiency programs. Energy 2006;31:1084-99.

[7] Gellings C, Smith W. Integrating demand-side management into utility planning. Proceedings of the IEEE June 1989;77(6).

[8] Waide P, Buchner B. Utility energy efficiency schemes: savings obligations and trading. Energy Efficiency 2008;1:297-311.

[9] Haney AB, Jamasb T, Platchkov LM, Pollitt MG. Demand-side management strategies and the residential sector: lessons from international experience. Electricity Policy Research Group, University of Cambridge; 2010.

[10] OCDE/IEA. The power to choose - demand response in liberalised electricity markets. Paris: International Energy Agency; 2003.
[11] Yu Y. Policy redesign for solving the financial bottleneck in demand side management (DSM) in China. Energy Policy 2010:6101-10.

[12] IEA. Energy efficiency governance. Paris: OECD/IEA; 2010.

[13] REEEP. Database: policy and regulation review. [Online] Available: http:// www.reeep.org/9353/policy-database.htm; 2012 [Accessed 05.02.12].

[14] Eberhard A, Shkaratan M. Powering Africa: meeting the financing and reform challenges. Energy Policy 2012;42:9-18.

[15] Balachandra P, Ravindranath D, Ravindranath NH. Energy Efficiency in India: assessing the policy regimes and their impacts. Energy Policy 2010;38:6428-38.

[16] IEA. "Energy policies of IEA countries: US 2007 review. Paris: OECD/IEA; 2008.

[17] Gillingham K, Newell RG, Palmer K. Retrospective examination of demandside energy efficiency policies. Washington: Resources for the Future; 2004.

[18] Eto J, Goldman C, Nadel S. Ratepayer-funded energy-efficiency programs in a restructured electricity industry: issues and options for regulators and legislators. Washington, D.C.: American Council for an Energy-Efficient Economy; 1998. 20036.

[19] Togeby, M. Danish DSM activities - current results and possible developments, In: IEEE power \& energy society general meeting, 2009. PES '09, Calgary, AB; 2009.

[20] IEA. Energy policies of IEA countries: Denmark 2006 review. Paris: OECD/IEA; 2006.

[21] ERSE. Plano de Promoção da Eficiência no Consumo de Energia Eléctrica para 2008. Lisboa: Entidade Reguladora dos Serviços Energéticos; 2007.

[22] ERSE. Plano de Promoção da Eficiência no Consumo de Energia Eléctrica para 2009-2010. Lisboa: Entidade Reguladora dos Serviços Energéticos; 2009.

[23] ERSE. Plano de Promoção da Eficiência no Consumo de Energia Eléctrica para 2011-2012. Lisboa: Entidade Reguladora dos Serviços Energéticos; 2010.

[24] IEA. Promoting energy efficiency: case studies in the residential sector. Paris: OECD/IEA; 2008.

[25] Nowak S, Kushler M, Sciortino M, York D, Witte P. Energy efficiency resource standards: state and utility strategies for higher energy savings. Washington, D.C: American Council for an Energy-Efficient Economy; 2011.

[26] ACEEE. State energy efficiency policy database - Massachusetts. [Online]. Available: http://www.aceee.org/energy-efficiency-sector/state-policy/massachusetts/ 193/all/191; 16 January 2012.

[27] Finamore B, Yew M, Ho B. Switchboard - natural resources defence council staff blog. [Online] Available: http://switchboard.nrdc.org/blogs/bfinamore/taking action_to_meet_its_clim.html; 29 November 2010 [Accessed 01.03.12].

[28] Jannuzzi GDM. Power sector reforms in Brazil and its impacts on energy efficiency and research and development activities. Energy Policy 2005;33: 1753-62.

[29] Boshell F, Veloza OP. Review of developed demand side management programs including different concepts and their results. In: Transmission and distribution conference and exposition: Latin America, 2008. Bogota: IEEE/ PES; 2008.

[30] Vine E. International DSM and DSM program evaluation: an INDEEP assessment. Energy 1996;21:983-96.

[31] Abhyankar N, Phadke A. Impact of large-scale energy efficiency programs on utility finances and consumer tariffs in India. Energy Policy 2012.. http:// dx.doi.org/10.1016/j.enpol.2012.01.008

[32] Spalding-Fecher R, Clark A, Davis M, Simmonds G. The economics of energy efficiency for the poor - a South African case study. Energy 2002;27:1099-117.

[33] Kushhler M, Vine E, York D. Using energy efficiency to help address electric systems reliability: an initial examination of 2001 experience. Energy 2003;28:303-17.. http://dx.doi.org/10.1016/S0360-5442(02)00117-2.

[34] Crossley DJ. Tradable energy efficiency certificates in Australia. Energy Efficiency 2008;I:267-81.

[35] Steinberger J, Niel J v, Bourg D. Profiting from negawats: reducing absolute consumption and emissions through a performance-based energy economy. Energy Policy 2009;37:361-70.

[36] IEA. Energy policies of IEA countries: UK 2006 review. Paris: OECD/IEA; 2007

[37] Clarke JA, Johnstone CM, Nicolas J, Kelly PA, Tyohy P. The role of built environment energy efficiency in a sustainable UK energy economy. Energy Policy 2008;36:4605-9.. http://dx.doi.org/10.1016/j.enpol.2008.09.004.

[38] Bertoldi P, Rezessy S, Lees E, Baudry P, Jeandel A, Labanca N. Energy supplier obligations and white certificate schemes: comparative analysis of experiences in the European Union. Energy Policy 2010;38:1455-69.. http:/l dx.doi.org/10.1016/j.enpol.2009.11.027.

[39] IEA. "Energy policies of IEA countries: France 2009 review. Paris: OECD/IEA; 2010.

[40] IEA. "Energy policies of IEA countries: Belgium 2009 review. Paris: OECD/IEA; 2010.

[41] Sovacool BK. The importance of comprehensiveness in renewable electricity and energy-efficiency policy. Energy Policy 2009;37:1529-41.

[42] Chomitz KM. Climate change and the world bank group: phase I: an evaluation of world bank win-win energy policy reforms. Washington D.C.: World Bank; 2009.

[43] Al-Badi AH, Malik A, Gastli A. Sustainable energy usage in Oman - opportunities and barriers. Renewable and Sustainable Energy Reviews 2011;15: 3780-8.

[44] Malik AS. Impact on power planning due to demand-side management (DSM) in commercial and governmental sectors with rebound effect - a case study of central grid of Oman. Energy 2007;32:2157-66.. http://dx.doi.org/10.1016/ j.energy.2007.05.004 
[45] ACEEE. State energy efficiency policy database. Retrieved from ACEEE American Council for and Energy-Efficient Economy: http://www.aceee.org/ energy-efficiency-sector/state-policy/alaska/176/all/191; 2012.

[46] RAP. State EE policy inventory for western states through 2010. Retrieved 07 26, 2012, from The Regulatory Assistance Project: http://www.raponline.org/ document/download/id/4741; 2011.

[47] RAP. State EE policy inventory for New England states through 2010. Retrieved 07 26, 2012, from Regulatory Assistance Project: http://www. raponline.org/document/download/id/4743; 2011.
[48] RAP. State EE policy inventory for Mid-Atlantic states through 2010. Retrieved 07 26, 2012, from The Regulatory Assistance Project: http://www.raponline. org/document/download/id/4744; 2011.

[49] RAP. State EE policy inventory for Southeastern states through 2010 Retrieved 07 26, 2012, from Regulatory Assistance Project: http://www. raponline.org/document/download/id/4742; 2011.

[50] RAP. State EE policy inventory for Midwestern states through 2010. Retrieved 07 26, 2012, from Regulatory Assistance Project: http://www.raponline.org/ document/download/id/4745; 2011. 